\title{
SOCIO-CULTURAL EFFECTS ON MENTAL HEALTH AND COMMON CHRONIC DISEASES IN PRIMARY CARE PATIENTS IN EAST AND WEST MOSTAR, BOSNIA AND HERZEGOVINA: PRELIMINARY RESULTS
}

\author{
Ivan Vasilj ${ }^{1}$, Marina Vasilj², Branka Aukst Margetić ${ }^{3}$, Ivo Curić ${ }^{1}$, Belma Sarić2 ${ }^{2}$ Bajro Sarić ${ }^{4}$, \\ Marko Martinac ${ }^{5}$, Dragan Babić ${ }^{1}$ and Milenko Bevanda ${ }^{1}$
}

\begin{abstract}
${ }^{1}$ School of Medicine, University of Mostar, ${ }^{2}$ Mostar University Hospital, Mostar, Bosnia and Herzegovina; ${ }^{3}$ Department of Psychiatry, Zagreb University Hospital Center, Zagreb, Croatia;

${ }^{4}$ Safet Mujić Regional Medical Center, ${ }^{5}$ Mostar Primary Care Center, Mostar, Bosnia and Herzegovina
\end{abstract}

\begin{abstract}
SUMMARY - Since war activities, the previously mixed population of Mostar, Bosnia and Herzegovina, live in segregated parts of the town based on ethnicity. The aim of this study was to examine differences in health risks and health status between populations of the two parts of the town. Health status of 300 randomly selected primary care patients was evaluated by practicing family physicians in two main primary care centers in West and East Mostar. Each group consisted of 150 patients. Data were collected between December 2013 and May 2014. Patients were evaluated for smoking habit, alcohol consumption, body mass index, blood pressure and laboratory measurement of fasting glycemia. Family physicians provided diagnosis of chronic noninfectious diseases (hypertension, diabetes mellitus, cardiovascular disease, malignant disease, depression, and alcoholism). The two groups differed according to age, income, employment status, and rate of alcoholism and hypertension. Alcoholism (OR= 4.105; 95\% CI 2.012-8.374) and hypertension (OR=1.972; 95\% CI 1.253-3.976) were associated with inhabitants of West Mostar, adjusted for age, employment and income status on logistic regression. In conclusion, ethnic differences between inhabitants of the two parts of the town might influence health outcomes. These are preliminary data and additional studies with larger samples and more specific questions considering nutrition and cultural issues are needed to detect the potential differences between the groups.
\end{abstract}

Key words: Health; Social determinants of health; Bosnia and Herzegovina; Ethnic groups; Religion; Cultural diversity; Alcoholism; Hypertension

\section{Introduction}

The breakup of Yugoslavia resulted in the establishment of the independent Republic of Bosnia and Herzegovina that, according to the Dayton agreement, consists of Federation of Bosnia and Herzegovina and Republic of Srpska. In the town of Mostar, situated in

Correspondence to: Branka Aukst Margetic, $M D, P h D$, Clinical Department of Psychiatry, Zagreb University Hospital Center, Kišpatićeva 12, HR-10000 Zagreb, Croatia

E-mail: branka.aukst-margetic@zg.t-com.hr

Received December 7, 2015, accepted March 30, 2016 the Federation of Bosnia and Herzegovina, the previously mixed Croatian and Bosniak populations live in separate communities ever since combat activities during the war. Mostar is a town with 113,449 inhabitants ${ }^{1}$. People belonging to Croatian ethnicity (mostly of Catholic religious denomination) almost exclusively inhabit the west part of the town, whereas people with Bosniak ethnic background (mostly of Muslim religious denomination) inhabit the east part of the town.

The society of Bosnia and Herzegovina still suffers from the consequences of war, which caused huge material costs and left a large number of refugees, killed 
or severely wounded people ${ }^{2,3}$. During the transition period, the whole population has been exposed to different psychosocial factors, psychological and physical stress, nutritional diseases, and lifestyle disorders that could influence development of different diseases, especially chronic noninfectious diseases such as cardiovascular diseases, psychiatric disorders, gastrointestinal disturbances, and malignant diseases ${ }^{4-6}$. In an attempt to provide a basis for better treatment and prevention strategies, we conducted screening of health epidemiological parameters among the citizens of Mostar. As different religious and cultural backgrounds might be associated with various health behaviors and outcomes, we assumed that the two communities might show differences in health status. Such differences have been described in several similar contexts in other cultures such as Arab and Jewish populations ${ }^{7,8}$. There are no studies that examined differences in epidemiological parameters based on ethnic relocation in the area of former Yugoslavia.

The aim of the study was to examine differences in health risks and health status in the populations of the two parts of the town twenty years after segregation, including alcohol abuse, smoking habit, incidence of chronic noninfectious diseases, malignant tumors, depression and sociodemographic factors that influence health conditions of the general population.

\section{Subjects and Methods}

Participants were enrolled in the study between December 2013 and May 2014 by practicing family physicians in the two main primary care centers in West and East Mostar. To prevent selection bias, every first and last outpatient seen by the physician on a working day and fulfilling the inclusion/exclusion criteria was enrolled. Evaluation was typically undertaken on one visit to the clinic; however, for non-fasting outpatients on the first visit, a second visit was arranged to obtain fasting blood samples. A total of 300 working-age patients (range 18-65 years) were included. Study protocol was approved by the Ethics Committees of the two primary care centers in East and West Mostar. After the purpose of the study had been explained, all participants provided their informed consent.

All participants completed a standardized face-toface questionnaire. Demographic data including age, education level, employment status, income, marital status, number of household members and area of residence (East/West) were collected.
Patients were evaluated for smoking habit, alcohol consumption, body mass index (BMI), blood pressure and laboratory measurement of fasting glycemia. Family physicians provided diagnosis of chronic noninfectious diseases (depression, alcoholism, hypertension, diabetes mellitus, cardiovascular disease and malignant disease). In this part of the study, we analyzed patients based on socio-cultural effects, i.e. whether they were inhabitants of West or East Mostar. Each group consisted of 150 participants.

Three readings of the sitting blood pressure measured on the left arm with mercury sphygmomanometer were obtained. The mean of the readings was the final blood pressure. Anthropometric measurements were taken after the participants had removed their shoes and heavy clothing and belts. Each subject's height, weight and waist circumference (WC) were determined by a trained nurse. WC was measured at the level midway between the lower costal margin and iliac crest. BMI (weight $[\mathrm{kg}] /$ height $\left[\mathrm{m}^{2}\right]$ ) was calculated and classified as underweight $\left(<18.5 \mathrm{~kg} / \mathrm{m}^{2}\right)$, normal weight $\left(18.5-24.9 \mathrm{~kg} / \mathrm{m}^{2}\right)$, overweight $(25-$ $\left.29.9 \mathrm{~kg} / \mathrm{m}^{2}\right)$, and obese $\left(\geq 30 \mathrm{~kg} / \mathrm{m}^{2}\right)^{9}$. There were no underweight patients in our sample.

The Alcohol Use Disorders Identification TestConsumption (AUDIT-C) was used to assess the presence of alcoholism. The AUDIT-C questionnaire is a reliable and valid screening instrument. It consists of just three questions and usually takes about a minute to complete. The cut-off value used was $\geq 4$ points for men and $\geq 3$ points for women coding the presence of hazardous drinking ${ }^{10}$.

Depression was coded if the patient was currently on antidepressants or psychotherapeutic treatment for depression. The rest of the sample were evaluated with the Patient Health Questionnaire (PHQ-9) ${ }^{11}$. The Patient Health Questionnaire (PHQ) is a diagnostic tool for mental disorders that is quick and easy for patients to complete. It scores each of the 9 DSM-IV criteria. Each of the nine questions of the PHQ-9 was evaluated on a 4-point rating scale, ranging from 0 (not at all) to 3 (nearly every day), summing up to a total score. Major depressive disorder was considered to be present if the score was $\geq 10$.

Hypertension was defined as being on current antihypertensive drugs or having an abnormal blood pressure reading according to the European Society of Cardiology (ESC) Cardiovascular Prevention Guidelines ${ }^{12}$. 
Diabetes was defined as being on antidiabetic drugs or having increased fasting blood glucose. Data on malignant disease were obtained from medical records.

Eleven patients refused to participate in the study but there were no gender and age differences between these patients and those taking part in the study. Exclusion criteria were age younger than 18 and older than 65 , not having permanent address, being too ill to participate and inability to comprehend the questions. Sociodemographic characteristics of the sample are presented in Table 1.

\section{Statistics}

Data were analyzed using SPSS version 20.0. Descriptive statistics was performed for all variables ac- cording to the part of the town. Two groups were compared for sociodemographic variables, noninfectious diseases and measured parameters using $\chi^{2}$-test. Logistic regression was used to adjust significant differences in health outcomes between the groups for sociodemographic variables. The crude odds ratios (COR) were compared to adjusted odds ratios (AOR) and their 95\% confidence intervals (95\% CI). The level of statistical significance was set at $\mathrm{p}<0.05$.

\section{Results}

The $\chi^{2}$-test was performed to analyze differences in sociodemographic variables, chronic noninfectious diseases and measured parameters between the two

Table 1. Sociodemographic data and differences between East and West Mostar

\begin{tabular}{|c|c|c|c|c|}
\hline Variable & East, n (\%) & West, n (\%) & $\chi^{2}$-test & $\mathrm{p}$ \\
\hline Gender (male) & $55(36.7)$ & $54(36.0)$ & 0.014 & 0.9 \\
\hline $\begin{array}{c}\text { Age (yrs) } \\
18-35 \\
36-50 \\
51-65\end{array}$ & $\begin{array}{c}44(29.3) \\
45(30) \\
61(40.7)\end{array}$ & $\begin{array}{l}30(20) \\
66(44) \\
54(36)\end{array}$ & 7.048 & 0.029 \\
\hline $\begin{array}{l}\text { Income }(\mathrm{KM}) \\
\quad<300 \\
300-500 \\
500-800 \\
\quad>800\end{array}$ & $\begin{array}{c}38(25.3) \\
68(45.3) \\
27(18) \\
17(11.3)\end{array}$ & $\begin{array}{c}18(12) \\
61(40.7) \\
29(19.3) \\
42(28)\end{array}$ & 18.187 & 0.0001 \\
\hline $\begin{array}{l}\text { Employment } \\
\text { employed } \\
\text { unemployed } \\
\text { retired }\end{array}$ & $\begin{array}{c}67(44.7) \\
51(34) \\
32(21.3)\end{array}$ & $\begin{array}{c}104(69.3) \\
37(24.7) \\
9(6)\end{array}$ & 23.136 & 0.0001 \\
\hline $\begin{array}{l}\text { Marital status } \\
\text { single } \\
\text { married } \\
\text { divorced } \\
\text { widowed }\end{array}$ & $\begin{array}{c}26(17.3) \\
109(72.7) \\
6(4) \\
9(6)\end{array}$ & $\begin{array}{c}14(2.3) \\
115(76.7) \\
4(2.7) \\
17(11.39\end{array}$ & 6.622 & 0.085 \\
\hline $\begin{array}{l}\text { Household members } \\
1-2 \\
3-4 \\
5-6 \\
>6\end{array}$ & $\begin{array}{c}42(28) \\
81(54) \\
24(16) \\
3(2)\end{array}$ & $\begin{array}{l}47(31.3) \\
78(52) \\
21(14) \\
4(2.7)\end{array}$ & 0.680 & 0.878 \\
\hline $\begin{array}{l}\text { Education } \\
\text { elementary } \\
\text { secondary } \\
\text { college } \\
\text { university } \\
\end{array}$ & $\begin{array}{c}18(12) \\
86(57.3) \\
6(4) \\
40(26.7) \\
\end{array}$ & $\begin{array}{c}9(6) \\
88(58.7) \\
5(3.3) \\
48(32) \\
\end{array}$ & 3.841 & 0.279 \\
\hline
\end{tabular}

$\mathrm{KM}=$ convertible mark 
Table 2. Differences in addictions, body mass index, chronic diseases and blood glucose between East and West Mostar

\begin{tabular}{|l|c|c|c|c|}
\hline Variable & East, $\mathrm{n}(\%)$ & West, $\mathrm{n}(\%)$ & $\chi^{2}$-test & $\mathrm{p}$ \\
\hline \multicolumn{4}{|c|}{ Habits/addiction } \\
\hline Alcoholism/yes & $14(9.3)$ & $46(30.7)$ & 22.623 & $\mathbf{0 . 0 0 0 1}$ \\
Smoking/yes & $56(37.3)$ & $64(42.7)$ & 1.986 & 0.37 \\
\hline \multicolumn{4}{|c|}{ Chronic disease } \\
\hline Body mass index: & & & 2.971 & 0.226 \\
$18.5-24-9 \mathrm{~kg} / \mathrm{m}^{2}$ & $69(46)$ & $56(37.3)$ & & \\
$25-29.9 \mathrm{~kg} / \mathrm{m}^{2}$ & $70(46.7)$ & $77(51.3)$ & & \\
$>30 \mathrm{~kg} / \mathrm{m}^{2}$ & $11(7.3)$ & $17(11.3)$ & & \\
\hline Hypertension/yes & $72(48)$ & $90(60)$ & 4.348 & $\mathbf{0 . 0 3 7}$ \\
Diabetes mellitus/yes & $35(23.3)$ & $30(20)$ & 0.491 & 0.48 \\
Depression/yes & $20(13.3)$ & $16(10.7)$ & 0.595 & 0.47 \\
\hline Malignant disease/yes & $4(2.7)$ & $9(6)$ & 2.979 & 0.225 \\
\hline Blood glucose: & & & 6.977 & 0.073 \\
$4.0-6.0 \mathrm{mmol} / \mathrm{L}$ & $110(73.3)$ & $90(60)$ & & \\
$6.1-8.0 \mathrm{mmol} / \mathrm{L}$ & $35(23.3)$ & $51(34)$ & & \\
$8.1-10.0 \mathrm{mmol} / \mathrm{L}$ & $3(2)$ & $3(2)$ & & \\
$>10.0 \mathrm{mmol} / \mathrm{L}$ & $2(1.3)$ & $6(4)$ & & \\
\hline
\end{tabular}

Table 3. Results of logistic regression analysis for alcoholism as dependent variable and inhabitation in East/West Mostar adjusted for confounding variables (age, income and employment)

\begin{tabular}{|l|c|c|c|c|c|c|}
\hline Variable & B & WALD & $p$ & OR & $95 \%$ CI & \\
\hline & Crude OR & & & & & \\
\hline East vs. West & 1.458 & 19.297 & 0.0001 & 4.297 & 2.242 & 8.234 \\
\hline & Adjusted OR & & & & & \\
\hline East vs. West & 1.412 & 15.071 & 0.0001 & 4.105 & 2012 & 8.374 \\
\hline
\end{tabular}

$\mathrm{B}=$ coefficient WALD $=$ Wald $\chi^{2}$-test OR $=$ odds ratio $; 95 \% \mathrm{CI}=95 \%$ confidence interval

Table 4. Results of logistic regression for hypertension as dependent variable and inhabitation of East/West Mostar and confunding variables

\begin{tabular}{|l|c|c|c|c|c|c|}
\hline Variable & $\mathrm{B}$ & WALD & $\mathrm{p}$ & OR & 95\% CI & \\
\hline East vs. West & Crude OR & & & & & \\
\hline East vs. West & $\begin{array}{c}\text { Adjusted OR* } \\
0.803\end{array}$ & 7.434 & 0.038 & 1.625 & 1.028 & 2.568 \\
\hline East vs. West & $\begin{array}{c}\text { Adjusted OR** } \\
-6.80\end{array}$ & 5.049 & 0.006 & 2.232 & 1.253 & 3.976 \\
\hline
\end{tabular}

$\mathrm{B}=$ coefficient; $\mathrm{WALD}=$ Wald $\chi^{2}$-test $\mathrm{OR}=$ odds ratio; $95 \% \mathrm{CI}=95 \%$ confidence interval; *adjusted for age, employment and income; **adjusted for age, employment, income and alcoholism

groups. Comparisons between the groups are illustrated in Table 1 for sociodemographic variables and Table 2 for addiction, chronic noninfectious diseases and measured parameters.
Considering sociodemographic parameters, people from the west and east part of the town differed according to age, employment status and income (Table 1). The population from West Mostar was older. The 
members of this group were more often employed, while in the group from East Mostar participants were more often unemployed or retired. East Mostar participants had lower income, and the difference was biggest in the groups with lowest and highest income. The groups did not differ according to gender, education level, marital status or number of household members.

Significant between-group differences were also found in the presence of alcoholism. The group from West Mostar was diagnosed with alcoholism more often (30.7\%) than the East Mostar population (9.3\%). The association between the presence of alcoholism and inhabitation of a particular part of the town was adjusted for age, employment status and income by logistic regression $(\mathrm{COR}=4.3 ; \mathrm{AOR}=4.1)$. The analysis showed that living in West Mostar increased the chances for alcoholism by 4.1 (Table 3 ).

The groups of East and West Mostar significantly differed according to the presence of hypertension. Hypertension was more common in the population of West Mostar. This association was adjusted for age, employment status, income and alcoholism by logistic regression. Upon adjustment for age, employment and income, COR of 1.625 increased to 2.232. After alcoholism was added to the model, OR changed to 1.972. The analysis showed that living in West Mostar increased the chances for having hypertension by 1.972 (Table 4).

There were no significant differences in the prevalence of diabetes mellitus, depression or malignant diseases between the two parts of the town.

\section{Discussion}

Health status of the population of the Federation of Bosnia and Herzegovina is a reflection of transitional processes, i.e. demographic, social, economic, and epidemiological factors. During the war, combat activities resulted in strong and strict ethnic division within the town of Mostar. The town inhabitants had to change their home locations based on ethnic background or they had to leave the town. Accordingly, the town population decreased by about $13.2 \%$ between the 1991 and 2013 censuses $^{1}$. Both ethnic groups are marked with religious and cultural differences. Based on the 2001 survey, there is very strong correlation between national and religious identity in Bosnia and
Herzegovina; 99\% of Muslims and Roman Catholics are also self-identified as Bosniaks and Croats, respectively ${ }^{13}$. This is the first report comparing these two entities for health outcomes twenty years after the division. Differences in health outcomes between the cultural and ethnic groups that inhabit the same territory have been previously described in other populations ${ }^{7,8}$. Both populations are Caucasian of mainly Slavic ancestry ${ }^{14}$, and genetic differences associated with recorded differences are not plausible, but cannot be completely excluded either.

Alcoholism has been causally related to more than 60 different medical conditions, in most but not all cases detrimental to public health, social, legal and economic consequences ${ }^{15}$. In 2010, the prevalence of alcohol abuse in the mixed population of Mostar was 9.9\% and the prevalence of alcohol addiction was $2.1 \%^{2}$, which corresponds to the rate of addiction in the general population of the Federation of Bosnia and Herzegovina (2.3\%). However, these data were not analyzed according to the ethnicity of the population ${ }^{16}$. Other available data point to a rate of $5 \%$ of alcohol abuse in the population of primary care patients ${ }^{17}$. Our findings obtained in primary care patients correspond to those previously published.

Differences in the rate of alcoholism between the East and West Mostar patient populations (i.e. alcoholism being diagnosed more frequently among the West Mostar inhabitants) could be interpreted based on cultural and religious background specificities of the two parts of the town. East Mostar is mostly inhabited by the population of Bosniak with highly predominant Muslim religious denomination, whereas West Mostar is predominantly of Catholic religious background. While Muslim religious denomination strictly prohibits alcohol consumption, Catholics are more permissive to $\mathrm{it}^{18}$. Epidemiological studies have shown lower prevalence of alcoholism in the predominantly Bosniak (Muslim) in comparison with Catholic population ${ }^{19}$. The reference group theory provides a rationale explaining why people of different religious groups display varying patterns of alcohol consumption. Block et al. suggest that moderate alcohol consumption is not proscribed by Catholic Church doctrine as there is no clear moral message against the use of alcohol ${ }^{20}$. A lower prevalence of Dupuytren's contracture, known to be associated with alcoholism, among Bosnian Muslim in comparison to Bosnian 
Serb and Croat men has been described ${ }^{21}$. Difference in alcoholism is also associated with financial income, as described in a previous research ${ }^{22}$. Although comorbidity of alcoholism and depression is well known ${ }^{22}$, the two samples did not differ in the prevalence of depression.

There were no significant differences between the two patient communities in smoking habits, yielding rates similar to those in Bosnia and Herzegovina in general ${ }^{5}$. Religious, cultural and moral proscriptions considering smoking do not differ between the two predominant religions.

Findings suggest that inhibiting effect by religiosity on deviance (including alcoholism) is more pronounced in communities where the majority of population are actively religious ${ }^{23}$. There are assumptions about the increase of religiosity in all ethnic groups in the Federation of Bosnia and Herzegovina after the split of former Yugoslavia ${ }^{19}$, so we can expect an increase in holding to religious and traditional cultural principles in both ethnicities ${ }^{24}$.

Other significant differences between the two populations were found for the diagnosis of hypertension, which was more prevalent in the population of West Mostar. The rate of hypertension in the general population of the Federation of Bosnia and Herzegovina was $42.1 \%$ according to a 2012 report $^{16}$. Religious backgrounds could probably be associated with nutrition, alcohol consumption and BMI, all of these corresponding to higher blood pressure. Moderate drinking has even been suggested to have a cardioprotective effect based on the effects on lipids and hemostatic factors, but the mechanism associated with this seem to apply only to those who have a pattern of regular drinking without heavy drinking occasions ${ }^{15}$.

Besides attitudes towards alcohol consumption, Muslim and Catholic religions also differ according to fat intake. Consumption of pork meat is forbidden by Muslim religious practice and so is the usage of pork fat and all kinds of pork processed meat. Our results show that patients from West Mostar had higher rates of hypertension if they were younger than 50. Differences in nutrition and rate of alcoholism (and maybe some other factors) could possibly lead to earlier development of hypertension, while in the older age group other common risk factors were comparable in the two groups. Of note is that the two groups did not differ according to BMI and that there were no underweight patients in the sample.
Study results revealed between-group differences according to economic factors. The patients from West Mostar earned more and were more often employed than the group of patients from East Mostar. General socioeconomic indicators pointed to a really difficult situation in the whole Federation of Bosnia and Herzegovina because of continuous increase in the number of unemployed persons, low gross domestic product, migrations, as well as a high rate of vulnerable groups in the general population (women, children, elderly, war victims and disabled persons) $)^{5,25,26}$. Our data point to even worse situation in the east part of the town of Mostar. The associations between socioeconomic status, dietary habits and health outcomes may differ based on various ethnic and cultural factors, but these associations are generally underresearched ${ }^{27,28}$.

Besides hypertension, the most important chronic noninfectious diseases in the Federation of Bosnia and Herzegovina population are cardiovascular diseases and diabetes mellitus ${ }^{4,29}$. The groups did not differ in the prevalence of diabetes, although there was a trend of higher blood glucose levels in the group from West Mostar. We may suppose that the same risk factors mentioned previously for hypertension are also of importance here. Our sample did not show difference between the two ethnic groups according to the rate of depression either, which is not unusual since both groups share poor socioeconomic situation. The rates correspond to those in the general population ${ }^{17}$. The two groups actually differed only in the domains (alcoholism, hypertension and nutrition) where religious and cultural issues could make the difference.

\section{Limitations}

The present study had several limitations. The size of the sample was modest. Our survey included only people attending primary care clinics; it therefore represented only those seeking medical care. The population of patients in primary care would likely represent varying levels of acuity and a variety of economic backgrounds. The sample was randomized, but clearly could not represent exactly the situation in the two populations. Actual presence and level or religiosity was not assessed, which should be done in the future to confirm our assumptions. We did not collect data on the volume of alcohol used or on the duration of particular illness. Our data reflect screening of epidemiological nature and need further exploration. Dietary 
habits of the population should be studied in more detail. Furthermore, there may be additional factors not assessed in this study that influenced the differences found between the two groups.

\section{Conclusion}

Nutrition, habits, religion, culture and health are inextricably intertwined ${ }^{30}$ and might influence health outcomes. Our data are preliminary, but raise several important questions that should be clarified. Future studies should be performed in the general population, including larger samples of different age groups and more specific questions considering nutrition and cultural issues to detect the potential differences between the groups.

\section{References}

1. Agency for Statistics of Bosnia and Herzegovina. Preliminary results of the 2013 census of population, households and dwellings in Bosnia and Herzegovina. Sarajevo; 2013.(cited 2015 August 17). Available at: http://www.bhas.ba/obavjestenja/ Preliminarni_rezultati_bos.pdf. (in Bosnian)

2. Skobić H, Sinanović O, Skobić Bovan N, Ivanković A, Pejanović Skobić N. Prevalence of alcohol abuse and alcoholism in general population of Mostar region, Bosnia and Herzegovina. Coll Antropol. 2010;34(Suppl 1):29-31.

3. Curić I, Curić S, Nikolić J, Vasilj I. Public health services in Herzegovina region during 1992-1995 war. Coll Antropol. 2010;34 (Suppl 1):321-4.

4. Bergovec M, Heim I, Vasilj I, Jembrek-Gostovic M, Bergovec M, Strnad M. Acute coronary syndrome and the 1992-1995 war in Bosnia and Herzegovina: a 10-year retrospective study. Mil Med. 2005;170:431-4. doi: http://dx.doi.org/10.7205/ MILMED.170.5.431

5. Vasilj I, Pilav A, Maslov B, Polašek O. Cardiovascular risk factors research in Bosnia and Herzegovina. Coll Antropol. 2009;33(Suppl 2):185-8.

6. Vasilj I, Cavaljuga S, Petrović P, Ostojić L, Ostojić Z, Kvesić A, et al. Cerebrovascular insult hospital cases in the Clinical Hospital Mostar (Bosnia and Herzegovina) from 1999 to 2003 - an example of an institutional register. Coll Antropol. 2006;30: 501-5.

7. Baron-Epel O, Kaplan G, Haviv-Messika A, Tarabeia J, Green MS, Nitzan Kaluski D. Self-reported health as a cultural health determinant in Arab and Jewish Israelis MABAT - National Health and Nutrition Survey 1999-2001. Soc Sci Med. 2005;61:1256-66. doi:10.1016/j.socscimed.2005.01.022

8. Kark JD, Gordon ES, Haklai Z. Coronary heart disease mortality among Arab and Jewish residents of Jerusalem. Lancet. 2000;365:1410-1. doi:10.1016/S0140-6736(00)02849-X
9. WHO. Obesity: preventing and managing the global epidemic. Report of a WHO Consultation. WHO Technical Report Series 894. Geneva: World Health Organization; 2000.

10. Bradley KA, DeBenedetti AF, Volk RJ, Williams EC, Frank D, Kivlahan DR. AUDIT-C as a brief screen for alcohol misuse in primary care. Alcohol Clin Exp Res. 2007;31:1208-17. doi: 10.1111/j.1530-0277.2007.00403.x

11. Kroenke K, Spitzer RL, Williams JB. The PHQ-9: validity of a brief depression severity measure. J Gen Intern Med. 2001; 16:606-13. doi: 10.1111/j.1525-1497.2006.00409.x

12. Graham I, Atar D, Borch-Johnsen K, Boysen G, Burell G, Cifkova $\mathrm{R}$, et al. European guidelines on cardiovascular disease prevention in clinical practice: executive summary. Eur Heart J. 2007;28:2375-414. doi: http://dx.doi.org/10.1093/eurheartj/ ehm 316

13. Agency for Statistics of Bosnia and Herzegovina. Preliminary results of the 2001 Census of Population, Households and Dwellings in Bosnia and Herzegovina. Sarajevo; 2001.[cited 2015 August 17] Available at: http://www.dzs.hr/Hrv/censuses/Census2001/census.htm

14. Marjanovic D, Fornarino S, Montagna S, Primorac D, Hadziselimovic R, Vidovic S, et al. The peopling of modern BosniaHerzegovina: Y-chromosome haplogroups in the three main ethnic groups. Ann Hum Genet. 2005;69:757-63. doi: 10.1111/j.1529-8817.2005.00190.x

15. Room R, Babor T, Rehm J. Alcohol and public health. Lancet. 2005;365:519-30. doi:10.1016/S0140-6736(05)17870-2

16. Ramić-Čatak A, Imamović E, Jokić, I, Gusinac-Škopo A. Adult Population Health Status Study in the Federation of Bosnia and Herzegovina in 2012. Sarajevo: Federal Ministry of Health; Mostar: Public Health Institute of Bosnia and Herzegovina Federation; 2014. (in Croatian)

17. Broers T, Hodgetts G, Batić-Mujanović O, Petrović V, Hasanagić M, Godwin M. Prevalence of mental and social disorders in adults attending primary care centers in Bosnia and Herzegovina. Croat Med J. 2006;47:478-84.

18. Ghandour LA, Karam EG, MaaloufWE. Lifetime alcohol use, abuse and dependence among university students in Lebanon: exploring the role of religiosity in different religious faiths. Addiction. 2009;104:940-8. doi: 10.1111/j.1360-0443.2009. 02575. $\mathrm{x}$

19. Klanjsek R, Vazsonyi AT, Trejos-Castillo E. Religious orientation, low self-control, and deviance: Muslims, Catholics, Eastern Orthodox-, and "Bible Belt" Christians. J Adolesc. 2012;35:671-82. doi:10.1016/j.adolescence.2011.09.003

20. Bock E W, Cochran JK, Beeghley L. Moral messages: the relative influence of denomination on the religiosity-alcohol relationship. Sociol Q. 1987;28:89-103.

21. Zerajic D, Finsen V. Dupuytren's disease in Bosnia and Herzegovina. An epidemiological study. BMC Musculoskelet Disord. [Internet] 2004 [cited 2015] August 20];5:10. Available at: http://www.biomedcentral.com/1471-2474/5/10 doi: 10.1186/ 1471-2474-5-10 
22. van Oers JA, Bongers IM, van de Goor LA, Garretsen HF. Alcohol consumption, alcohol-related problems, problem drinking, and socioeconomic status. Alcohol Alcohol. 1999;34(1):78-88. doi: http://dx.doi.org/10.1093/alcalc/34.1.78

23. Stark R. Religion as context: hellfire and delinquency one more time. Sociol Relig. 1996;57:163-73. doi: 10.2307/3711948

24. Hacic-Vlahovic A. (De)Secularization in Bosnia-Herzegovina - an examination of religiosity trends in a multi-ethnic society. Amsterdam Soc Sci. 2008;1:72-86.

25. Bergovec M, Vasilj I. Bosnia and Herzegovina and Croatia: the medicalisation of the experience of war. Lancet. 1999;354:7712. doi: 10.1016/S0140-6736(99)90154-X

26. Ivanković A, Ravlija J, Skobić H, Vasilj I, Ivanković Z, Pejanović-Skobić N, et al. Health status of population in Federation of Bosnia and Herzegovina in 15 years of transitional period. Coll Antropol. 2010;34(Suppl. 1):325-33.
27. Vlismas K, Stavrinos V, Panagiotakos DB. Socio-economic status, dietary habits and health-related outcomes in various parts of the world: a review. Cent Eur J Public Health. 2009;17: 55-63.

28. Mollaoğlu M, Solmaz G, Mollaoğlu M. Adherence to therapy and quality of life in hypertensive patients. Acta Clin Croat. 2015;54(4):438-44.

29. Pilav A. Final report of the implementation of the risk factors prevention program in primary care and family physicians teams for registered patients with data analysis: pilot project in Canton Sarajevo and West Herzegovina district in 2006-2007. Sarajevo: Public Health Institute of Bosnia and Herzegovina Federatione; 2008. (in Bosnian)

30. Glanz K, Kolonel LN. Culture, religion, diet and health: challenges and opportunities. Nutrition. 1998;14:238-9. doi: 10.1016/S0899-9007(97)00424-3

\title{
Sažetak \\ UČINAK SOCIO-KULTUROLOŠKIH ČIMBENIKA NA MENTALNO ZDRAVLJE I ČESTE KRONIČNE BOLESTI U PACIJENATA OPĆE MEDICINE U ISTOČNOM I ZAPADNOM MOSTARU, BOSNA I HERCEGOVINA: PRELIMINARNI REZULTATI
}

\author{
I. Vasilj, M. Vasilj, B. Aukst Margetic, I. Curic, B. Saric, B. Saric, M. Martinac, D. Babić i M. Bevanda
}

Ranije miješana populacija Mostara u Bosni i Hercegovini od rata živi u dijelovima grada podijeljenim na osnovi etničke pripadnosti. Cilj istraživanja bio je ispitati razlike u zdravstvenim rizicima i zdravstvenom statusu između populacija dvaju dijelova grada. Obiteljski liječnici dvaju domova zdravlja istočnog i zapadnog Mostara ispitali su zdravstveni status 300 slučajno izabranih ambulantnih pacijenata. Svaka skupina sastojala se od 150 pacijenata. Podaci su prikupljani između prosinca 2013. i svibnja 2014. godine. Prikupljeni su podaci o pušenju, konzumaciji alkohola, indeksu tjelesne težine, krvnom tlaku i laboratorijski mjerenoj glukozi natašte. Dijagnoze kroničnih nezaraznih bolesti (hipertenzija, dijabetes melitus, kardiovaskularne bolesti, maligne bolesti, depresija i alkoholizam) utvrdili su liječnici obiteljske medicine. Dvije skupine razlikovale su se prema dobi, prihodima, zaposlenju, zastupljenosti alkoholizma i hipertenzije. Alkoholizam (OR=4,105; 95\% CI 2,012$8,374)$ i hipertenzija (OR=1,972; 95\% CI 1,253-3,976) povezani su sa stanovanjem u zapadnom Mostaru prilagođeno za dob, zaposlenje i zaradu u logističkoj regresiji. Zaključno, etničke razlike između stanovnika dvaju dijelova grada mogu utjecati na zdravstvene ishode. Ovo su preliminarni podaci i potrebna su dodatna istraživanja s većim uzorcima i specifičnim pitanjima vezano uz prehranu i kulturološka pitanja za otkrivanje mogućih razlika među ovim skupinama.

Ključne riječi: Zdravlje; Socijalne odrednice zdravlja; Bosna i Hercegovina; Etničke skupine; Religija; Kuturološka raznolikost; Alkoholizam; Hipertenzija 